\title{
Ripening Stage Affects the Chilling Sensitivity of Greenhouse-grown Peppers
}

\author{
W.C. Lin $^{1}$ \\ Agriculture Canada, Research Station, P.O. Box 1000, Agassiz, B.C. V0M 1A0, Canada
}

J.W. Hall

Agriculture Canada, Vancouver Research Station, 6660 Northwest Marine Drive, Vancouver, B.C. V6T 1X2, Canada

M.E. Saltveit, Jr.

Mann Laboratory, Department of Vegetable Crops, University of California, Davis, CA 95616-8631

Additional index words. Capsicum annuum, carbon dioxide, coloration, ethylene, postharvest

\begin{abstract}
Greenhouse-grown 'Bison' and 'Doria' peppers (Capsicum annuum L.) were harvested when mature green (MG) (>95\% surface green) or ripe (>95\% of surface red or yellow). Both cultivars responded similarly to temperature and neither exhibited chilling injury (CI), as indicated by surface pitting, after storage at 13C for 1 or 2 weeks. Ripe peppers showed no CI when held at $1 \mathrm{C}$ for 1 or 2 weeks, while MG peppers exhibited CI after these treatments. Exposing MG peppers to $1 \mathrm{C}$ for 3 days caused $\mathrm{CI}$ and stimulated $\mathrm{C}_{2} \mathrm{H}_{4}(\mathbf{1 2 . 3 x})$ and $\mathrm{CO}_{2}$ production $(2.5 \mathrm{x})$. In contrast, a similar exposure of ripe peppers did not cause $\mathrm{CI}$ but stimulated $\mathrm{C}_{2} \mathrm{H}_{4}(6.5 \mathrm{x})$ and $\mathrm{CO}_{2}$ production (1.4x). It seems that $\mathrm{CO}_{2}$ and $\mathrm{C}_{2} \mathrm{H}_{4}$ production was stimulated by exposure to $1 \mathrm{C}$, not necessarily by $\mathrm{CI}$ development. Our data question the physiological significance of elevated $\mathrm{CO}_{2}$ and $\mathrm{C}_{2} \mathrm{H}_{4}$ production in $\mathrm{CI}$ development. The observed tolerance of ripe peppers to 1C suggests that ripe greenhouse-grown peppers can be stored at temperatures lower than those currently recommended for bell peppers.
\end{abstract}

Chilling injury $(\mathrm{CI})$ is a physiological disorder of many economically important crops that were indigenous to the tropics and subtropics (Saltveit and Morris, 1990). Exposing these chillingsensitive crops to nonfreezing temperatures $<12 \mathrm{C}$ causes a myriad of symptoms that include uneven and abnormal ripening, increased water loss and surface pitting, increased $\mathrm{CO}_{2}$ and $\mathrm{C}_{2} \mathrm{H}_{4}$ production upon warming, increased susceptibility to certain diseases, and increased permeability of cellular membranes (e.g., ion leakage). CI becomes progressively more severe during storage for long periods or at low temperatures (Risse et al., 1987). Sweet bell peppers are susceptible to CI at nonfreezing temperatures <7C (Wang, 1977). The visible symptom of pitting occurs after peppers are returned to higher, nonchilling temperatures (e.g., 20C) (Miller and Risse, 1986; Wang and Baker, 1979).

Chilling temperatures stimulate $\mathrm{CO}_{2}$ production in cucumbers (Cucumis sativus L.) (Cabrera and Saltveit, 1990) and peppers (Kozukue and Ogata, 1972) and $\mathrm{C}_{2} \mathrm{H}_{4}$ production in papayas (Carica papaya L.) (Chan et al., 1985), cucumbers (Cabrera and Saltveit, 1990; Wang and Adams, 1982), and peppers (Yao et al., 1986). In higher plants, $\mathrm{C}_{2} \mathrm{H}_{4}$ is synthesized by the conversion of 1-aminocyclopropane-1-carboxylic acid (ACC) to $\mathrm{C}_{2} \mathrm{H}_{4}$ by ACC oxidase (Yang, 1980).

ACC oxidase was previously termed the ethylene-forming enzyme (Abeles et al., 1992). The rate of $\mathrm{C}_{2} \mathrm{H}_{4}$ synthesis in chilled cucumbers is limited by the availability of ACC and partially limited by ACC oxidase activity (Cabrera and Saltveit, 1990).

Differences in chilling sensitivity have been reported for tomatoes (Lycopersicon esculentum Mill.) of different maturities (Autio and Bramlage, 1986; King and Ludford, 1983). Using different

Received for publication 18 Mar. 1992. Accepted for publication 15 Mar. 1993 Contribution no. 459 of Agassiz Research Station, Agriculture Canada. We acknowledge the most skillful technical assistance of Glenn Block. The cost of publishing this paper was defrayed in part by the payment of page charges. Under postal regulations, this paper therefore must be hereby marked advertisement solely to indicate this fact.

${ }^{1}$ To whom reprint requests should be addressed. methods, however, similar patterns of chilling sensitivity were found in conditioned MG and red-ripe tomatoes (Saltveit, 1991). Most field-grown sweet bell peppers are commercially harvested at the MG stage and, thus, much of the previous research on CI in peppers has been conducted with MG fruit (Miller and Risse, 1986; Phelps and McDonald, 1989; Wang, 1977). Greenhouse-grown peppers, however, are usually harvested at the fully ripe stage (Bakker, 1989). The ripening (coloration) of bell peppers was studied by Saltveit (1977), but the effect of ripening on CI of greenhouse-grown peppers was not investigated.

The objectives of this study were to investigate the chilling sensitivity of two pepper cultivars and of peppers at different stages of maturity and to see if chilling stimulated $\mathrm{CO}_{2}$ and $\mathrm{C}_{2} \mathrm{H}_{4}$ production by these greenhouse-grown peppers.

\section{Materials and Methods}

Plant materials. Seeds of the commercial sweet bell peppers 'Bison' and 'Doria' (Bruinsma Seeds, Netherlands), red- and yellow-fruited, respectively, were sown on 24 Jan. 1991 on rockwool cubes and transplanted into 20-liter sawdust bags on 22 Mar. Plants were grown in a greenhouse under natural daylight using standard cultural practices (B.C. Ministry of Agriculture and Fisheries, 1988). The greenhouse was held at 28/19C (maximum/ minimum), and relative humidity $(\mathrm{RH})$ was $\approx 70 \%$.

Experimental procedures. MG fruit ( $>95 \%$ of surface green) and ripe fruit ( $>95 \%$ of surface red or yellow) were harvested on 25 June and 15 July and stored at 1 (chilling temperature) or 13C (control) for 1 or 2 weeks. The average $\mathrm{RH}$ in the 1 and 13C rooms was $98 \%$ [vapor-pressure deficit $(\mathrm{VPD})=0.013 \mathrm{kPa}$ ] and $95 \%$ $(\mathrm{VPD}=0.0075 \mathrm{kPa})$, respectively. The experiment was a $2^{5}$ factorial, with harvest $\times$ cultivar $\times$ maturity $\times$ temperature $\times$ storage time. In addition, freshly harvested fruit were analyzed. There were two greenhouse blocks (north and south). On 25 June, the experimental unit for each treatment consisted of seven fruit. On 15 July, four fruit from each of these two blocks were combined as 
a single experimental unit due to the limited number of fruit. Each experimental unit was assigned randomly to a temperature $\times$ storage time combination (Table 1).

To determine $\mathrm{CO}_{2}$ and $\mathrm{C}_{2} \mathrm{H}_{4}$ production, an experimental unit of seven (25 June) or eight (15 July) fruit was removed from storage and five to six fruit were sealed in a 6-liter container for $4 \mathrm{~h}$. After $1 \mathrm{~h}, 0.25-\mathrm{ml}$ gas samples were analyzed for $\mathrm{CO}_{2}$ production using a gas chromatograph (model GC-9A, Shimadzu Corp., Kyoto, Japan) equipped with a $1.5-\mathrm{m}$ poropak-Q column, a methanizer (model MTN-1, Shimadzu), and a flame ionization detector. Gas samples $(2.0 \mathrm{ml})$ were analyzed after $4 \mathrm{~h}$ for $\mathrm{C}_{2} \mathrm{H}_{4}$ with a gas chromatograph (model 3700; Varian Instrument Corp., Palo Alto, Calif.) equipped with a 2-m activated alumina column and a flame ionization detector. Each experimental unit constituted a replication. There were three replications: two on 25 June and one on 15 July.

On 26 June and 16 July, eight disks (9 $\mathrm{mm}$ in diameter) were excised randomly from each of two fruit from each experimental unit. Disks were incubated with $10 \mu \mathrm{l}$ of $50 \mu \mathrm{M}$ ACC or distilled water for $5 \mathrm{~h}$ in a petri dish, weighed, and sealed in a 10-ml hypovial (serumtype reaction vial 3-3104, Supelco, Oakville, Ontario) for $1 \mathrm{~h}$. The difference in $\mathrm{C}_{2} \mathrm{H}_{4}$ production with and without $\mathrm{ACC}$ was used to calculate ACC oxidase activity (Cabrera and Saltveit, 1990). A sample consisting of $50 \mathrm{~g}$ fresh weight from the same fruit was diced and homogenized with $100 \mathrm{ml}$ of cold $2 \% \mathrm{HCl}$ for 2 min (Lau et al., 1984). The homogenate was centrifuged at $1800 \mathrm{~g}$ for $20 \mathrm{~min}$. The supernatant was adjusted to $\mathrm{pH} 7.0$ with $10 \mathrm{M} \mathrm{NaOH}$. A 7.0-ml aliquot was reacted with $\mathrm{NaOCl}$ in the presence of $\mathrm{Hg}$ to determine ACC by measuring $\mathrm{C}_{2} \mathrm{H}_{4}$ production (Lizada and Yang, 1979).

Pitting of the fruit surface was rated visually by estimating the percentage of the surface affected at 1,3 , and 7 days after transfer to a room at 20 to $22 \mathrm{C}$ and $65 \% \mathrm{RH}(\mathrm{VPD}=0.82 \mathrm{kPa})$. Only the data obtained after 7 days of transfer to room temperature are reported.

MG fruit of 'Bison' and 'Doria' were harvested from a single block on 6 and 27 Aug. Production of $\mathrm{CO}_{2}$ and $\mathrm{C}_{2} \mathrm{H}_{4}$ was measured following the temperature treatments andmethods describedabove. Internal $\mathrm{CO}_{2}$ and $\mathrm{C}_{2} \mathrm{H}_{4}$ concentrations were measured from three fruit by withdrawing $0.25 \mathrm{ml}$ and $2.0 \mathrm{ml}$, respectively, directly from fruit when they reached room temperature.

Statistical analysis. SAS's general linear model procedure (SAS Institute, Cary, N.C.) was used for analysis of variance. To correct for the imbalance in the data, means were estimated by least squares. To provide homogeneous variances, some variables were transformed to logarithms for analysis. When this was done, backtransformed means and relative SES are presented. The SE for a mean is the product of the mean and the relative SE.

\section{Results}

CI symptom occurrence in fruit stored at $1 \mathrm{C}$ varied with ripening stage. Only $\mathrm{MG}$ fruit stored at $1 \mathrm{C}$ for 1 or 2 weeks developed surface pitting (Table 1). In MG fruit stored 1 week at $1 \mathrm{C}$, pitting became visible after 1 day at room temperature (20C). Compared to freshly harvested MG fruit, chilled MG fruit showed no change in $\mathrm{CO}_{2}$ production, elevated (18x) $\mathrm{C}_{2} \mathrm{H}_{4}$ production, reduced ( $0.3 \mathrm{x})$ ACC oxidase activity, and an elevated (3x) ACC concentration. In contrast, ripe yellow and red peppers showed no $\mathrm{CI}$ after 1 or 2 weeks at $1 \mathrm{C}$. After 1 week at $1 \mathrm{C}$, ripe peppers showed no change in $\mathrm{CO}_{2}$ production, elevated $(7 \mathrm{x}) \mathrm{C}_{2} \mathrm{H}_{4}$ production, reduced (0.3x) ACC oxidase activity, and an elevated (2x) ACC concentration.

No CI symptoms occurred in $\mathrm{MG}$ or ripe fruit stored at $13 \mathrm{C}$ for 1 or 2 weeks (Table 1). After 1 week, MG fruit stored at $13 \mathrm{C}$ showed reduced $(0.4 \mathrm{x}) \mathrm{CO}_{2}$ production, unchanged $\mathrm{C}_{2} \mathrm{H}_{4}$ produc- tion, reduced (0.5x) ACC oxidase activity, and an elevated (3x) ACC concentration. After 1 week of storage at $13 \mathrm{C}$, ripe fruit showed reduced $(0.6 \mathrm{x}) \mathrm{CO}_{2}$ production, unchanged $\mathrm{C}_{2} \mathrm{H}_{4}$ production, reduced $(0.4 \mathrm{x})$ ACC oxidase activity, and an elevated $(2 \mathrm{x})$ ACC concentration.

MG fruit showed CI after 3 days of storage at 1C (Table 2). These fruit had slightly increased (1.2x) internal $\mathrm{CO}_{2}$ but decreased $(0.7 x) \mathrm{CO}_{2}$ production. The corresponding internal $\mathrm{C}_{2} \mathrm{H}_{4}$ concentration increased $(48 \mathrm{x})$, as did $\mathrm{C}_{2} \mathrm{H}_{4}$ production $(5 \mathrm{x}) . \mathrm{MG}$ fruit showed no CI at $13 \mathrm{C}$.

CI was associated with high $\mathrm{CO}_{2}(r=0.54, P=0.0005, \mathrm{n}=37)$ and $\mathrm{C}_{2} \mathrm{H}_{4}(r=0.86, P=0.0001, \mathrm{n}=36)$ production. However, $\mathrm{CI}$ was not associated with ACC oxidase activity $(r=0.02, P=0.89$, $\mathrm{n}=34)$ or ACC concentration $(r=0.29, P=0.07, \mathrm{n}=37)$.

There were no differences between 'Bison' (red fruit) and 'Doria' (yellow fruit) in surface pitting, ACC oxidase activity, or ACC concentration (Tables 1 and 2). 'Bison' $\mathrm{CO}_{2}$ production was $3.2 \mathrm{ml} \cdot \mathrm{kg}^{-1} \cdot \mathrm{h}^{-1}(\mathrm{SE}=0.88)$ lower in ripe red fruit than in MG fruit, but for 'Doria' it was $1.7 \mathrm{ml} \cdot \mathrm{kg}^{-1} \cdot \mathrm{h}^{-1}$ higher in ripe yellow fruit (significant cultivar $\times$ ripeness interaction). The effect of storage temperature on $\mathrm{C}_{2} \mathrm{H}_{4}$ production, which was measured after $2 \mathrm{~h}$ in a sealed container, differed in the two cultivars (significant interaction). For the fruit harvested in June and July, 'Bison' $\mathrm{C}_{2} \mathrm{H}_{4}$ production was $269 \mathrm{nl} \cdot \mathrm{kg}^{-1} \cdot \mathrm{h}^{-1}(\mathrm{SE}=67)$ lower after storage at $13 \mathrm{C}$ than after storage at $1 \mathrm{C}$ when measured at 20C, while for 'Doria', the difference was $558 \mathrm{nl} \cdot \mathrm{kg}^{-1} \cdot \mathrm{h}^{-1}$. In the fruit harvested in August, the differences were 213 and $79 \mathrm{nl} \cdot \mathrm{kg}^{-1} \cdot \mathrm{h}^{-1}(\mathrm{SE}=30)$ respectively. At the $6 \mathrm{Aug}$. harvest, $\mathrm{C}_{2} \mathrm{H}_{4}$ production was similar in the two cultivars; but, in fruit harvested 27 Aug., $\mathrm{C}_{2} \mathrm{H}_{4}$ production was 55 $\mathrm{nl} \cdot \mathrm{kg}^{-1} \cdot \mathrm{h}^{-1}(\mathrm{SE}=35)$ higher in 'Bison' and $79 \mathrm{nl} \cdot \mathrm{kg}^{-1} \cdot \mathrm{h}^{-1}$ lower in 'Doria' than fruit harvested on 6 Aug. (significant cultivar $\times$ harvest date interaction).

\section{Discussion}

Ripening. When greenhouse-grown bell peppers ripened from $\mathrm{MG}$ to yellow or red, there was no change in $\mathrm{CO}_{2}$ and a decrease in $\mathrm{C}_{2} \mathrm{H}_{4}$ production. The decrease in $\mathrm{C}_{2} \mathrm{H}_{4}$ production probably resulted from the reduced $\mathrm{ACC}$ oxidase activity, since there was no change in ACC concentration (Table 1). The patterns of $\mathrm{CO}_{2}$ and $\mathrm{C}_{2} \mathrm{H}_{4}$ production are in contrast to those of Saltveit (1977), who showed that internal $\mathrm{CO}_{2}$ and $\mathrm{C}_{2} \mathrm{H}_{4}$ concentrations increased during ripening of harvested bell peppers. This difference may be due to the fact that the fruit ripened on the plants in this study but ripened after harvest in Saltveit's study. The increase in the internal $\mathrm{CO}_{2}$ and $\mathrm{C}_{2} \mathrm{H}_{4}$ concentrations was greater than the increase in $\mathrm{CO}_{2}$ and $\mathrm{C}_{2} \mathrm{H}_{4}$ production (Table 2).

Pitting occurred in MG peppers stored at $1 \mathrm{C}$ for as little as 3 days and increased in severity during 2 weeks of storage (Tables 1 and 2). Similar levels of chilling sensitivity have been reported for bell peppers (Miller and Risse, 1986; Wang and Baker, 1979). Ripe peppers showed no CI (Table 1). The observed difference in CI between MG and ripe peppers was similar to the decrease in CI of tomatoes with increasing maturity (Autio and Bramlage, 1986). This finding is of practical importance since it seems that ripe greenhouse-grown peppers can be stored for a few weeks at lower temperatures than the 7 to $13 \mathrm{C}$ recommended for $\mathrm{MG}$ fruit (Hardenburg et al., 1986).

Pitting after chilling is intensified by increased water loss in low vs. high RH (Morris and Platenius, 1939). Elevated water loss was associated with severe pitting in a separate experiment in which the effect of the number of film perforations in storage bags was tested (unpublished data). 
Table 1. Effects of ripeness stage ${ }^{\mathrm{z}}$, storage temperature, and storage time on percentage surface pitting, $\mathrm{CO}_{2}$ and $\mathrm{C}_{2} \mathrm{H}_{4}$ production, ACC oxidase activity, and ACC concentration of greenhouse-grown peppers.

\begin{tabular}{|c|c|c|c|c|c|c|}
\hline $\begin{array}{l}\text { Storage } \\
\text { temperature } \\
\left({ }^{\circ} \mathrm{C}\right)\end{array}$ & $\begin{array}{l}\text { Storage } \\
\text { time } \\
\text { (wk) }\end{array}$ & $\begin{array}{c}\text { Surface } \\
\text { pitting } \\
(\%)\end{array}$ & $\begin{array}{c}\mathrm{CO}_{2} \text { production } \\
\left(\mathrm{ml} \cdot \mathrm{kg}^{-1} \cdot \mathrm{h}^{-1}\right)\end{array}$ & $\begin{array}{l}\mathrm{C}_{2} \mathrm{H}_{4} \text { production } \\
\left(\mathrm{nl} \cdot \mathrm{kg}^{-1} \cdot \mathrm{h}^{-1}\right)\end{array}$ & $\begin{array}{l}\text { ACC oxidase } \\
\left(\mathrm{nl} \cdot \mathrm{kg}^{-1} \cdot \mathrm{h}^{-1}\right)\end{array}$ & $\begin{array}{c}\mathrm{ACC} \\
\left(\mathrm{nmol} \cdot \mathrm{g}^{-1}\right) \\
\text { (fresh equiv.) }\end{array}$ \\
\hline \multicolumn{7}{|c|}{ Mature-green fruit } \\
\hline Fresh harvest & 0 & 0 & 19.7 & 60 & 636 & 0.0094 \\
\hline 13 & 1 & 0 & 8.0 & 65 & 298 & 0.0283 \\
\hline 13 & 2 & 0 & 6.5 & 73 & 328 & 0.0156 \\
\hline 1 & 1 & 57 & 18.3 & 1085 & 201 & 0.0275 \\
\hline 1 & 2 & 60 & 17.7 & 610 & 167 & 0.0572 \\
\hline \multicolumn{7}{|c|}{ Ripe fruit } \\
\hline Fresh harvest & 0 & 0 & 18.7 & 39 & 279 & 0.0141 \\
\hline 13 & 1 & 0 & 10.6 & 43 & 107 & 0.0324 \\
\hline 13 & 2 & 0 & 10.5 & 43 & 71 & 0.0170 \\
\hline 1 & 1 & 0 & 15.1 & 264 & 88 & 0.0334 \\
\hline 1 & 2 & 0 & 15.2 & 296 & 59 & 0.0509 \\
\hline Relative SE & & 4.0 & $0.95^{y}$ & 0.256 & 456 & 0.194 \\
\hline \multicolumn{7}{|l|}{ Significance } \\
\hline Cultivar & & NS & NS & NS & NS & NS \\
\hline Harvest & & $* *$ & $* *$ & $* *$ & $* * *$ & NS \\
\hline Ripening (R) & & $* * *$ & NS & $*$ & $* *$ & NS \\
\hline Temperature $(\mathrm{T})$ & & $* * *$ & $* * *$ & $* * *$ & NS & $* * *$ \\
\hline Storage time (D) & & $* * *$ & NS & NS & NS & NS \\
\hline $\mathrm{R} \times \mathrm{T}$ & & $* * *$ & $* * *$ & NS & NS & NS \\
\hline $\mathrm{T} \times \mathrm{D}$ & & NS & NS & NS & NS & $* * *$ \\
\hline $\mathrm{R} \times \mathrm{D}$ & & $* * *$ & NS & NS & NS & NS \\
\hline $\mathrm{R} \times \mathrm{T} \times \mathrm{D}$ & & NS & NS & NS & NS & NS \\
\hline
\end{tabular}

${ }^{\mathrm{z}}$ Mature-green, $>95 \%$ of surface green; ripe, $>95 \%$ of surface red or yellow.

${ }^{\mathrm{y}} \mathrm{SE}$ for $\mathrm{CO}_{2}$ production

ns, ${ }^{* * * * * * * *}$ Nonsignificant or significant at $P \leq 0.05,0.01,0.001$ respectively.

Table 2. Effect of storage temperature and time on percentage surface pitting, $\mathrm{CO}_{2}$ and $\mathrm{C}_{2} \mathrm{H}_{4}$ production, and internal $\mathrm{CO}_{2}$ and $\mathrm{C}_{2} \mathrm{H}_{4}$ concentrations of mature-green peppers.

\begin{tabular}{|c|c|c|c|c|c|c|}
\hline $\begin{array}{l}\text { Storage } \\
\text { temperature } \\
\left({ }^{\circ} \mathrm{C}\right)\end{array}$ & $\begin{array}{c}\text { Storage } \\
\text { time } \\
\text { (day) }\end{array}$ & $\begin{array}{l}\text { Pitting } \\
(\%)\end{array}$ & $\begin{array}{l}\mathrm{CO}_{2} \text { production } \\
\left(\mathrm{ml} \cdot \mathrm{kg}^{-1} \cdot \mathrm{h}^{-1}\right)\end{array}$ & $\begin{array}{c}\mathrm{C}_{2} \mathrm{H}_{4} \text { production } \\
\left(\mathrm{nl} \cdot \mathrm{kg}^{-1} \cdot \mathrm{h}^{-1}\right)\end{array}$ & $\begin{array}{c}\mathrm{CO}_{2} \text { internal } \\
(\%)\end{array}$ & $\begin{array}{c}\mathrm{C}_{2} \mathrm{H}_{4} \text { internal } \\
(\mathrm{ppb})\end{array}$ \\
\hline Fresh harvest & 0 & 0 & 22.8 & 61 & 3.27 & 44 \\
\hline \multirow[t]{3}{*}{13} & 1 & 0 & 13.6 & 56 & 2.89 & 44 \\
\hline & 3 & 0 & 11.5 & 146 & 2.59 & 145 \\
\hline & 7 & 0 & 5.7 & 46 & 1.09 & 65 \\
\hline \multirow[t]{3}{*}{1} & 1 & 0 & 13.0 & 80 & 3.22 & 158 \\
\hline & 3 & 29 & 16.2 & 298 & 3.97 & 2118 \\
\hline & 7 & 50 & 12.3 & 299 & 4.47 & 2659 \\
\hline SE & & 7.7 & 0.50 & $0.1^{z}$ & 0.183 & 0.2 \\
\hline \multicolumn{7}{|l|}{ Significance } \\
\hline Cultivar & & NS & $*$ & NS & NS & NS \\
\hline Temperature $(\mathbf{T})$ & & $* *$ & $* * *$ & $* * *$ & $* * *$ & $* *$ \\
\hline Storage time (D) & & $*$ & $* * *$ & $* *$ & NS & $* *$ \\
\hline $\mathrm{T} \times \mathrm{D}$ & & NS & $* *$ & $*$ & $* *$ & $* *$ \\
\hline
\end{tabular}

Ns, ${ }^{* * *}, * * * *$ Nonsignificant or significant at $P \leq 0.05,0.01,0.001$, respectively.

Water loss was negatively associated with pitting and the likely degree of waxiness of the surface of zucchini squash (Mencarelli et al., 1983). The ground spot that likely had lower wax content than the upper part of the zucchini squash developed more severe CI than the top. In contrast, wrapping MG peppers in plastic films (a treatment that should have reduced water loss) did not reduce CI (Miller and Risse, 1986). Our preliminary study with MG peppers showed that pitting occurred at 1 but not $13 \mathrm{C}$, while water loss was similar at the two temperatures; $1.5 \%$ and $1.3 \%$, respectively. Ripe and MG fruit had similar water loss during 12 days at $1 \mathrm{C}(1.5 \%$ and $1.3 \%$, respectively), while pitting was absent in ripe fruit and $15 \%$ in MG fruit. The ripe and MG greenhouse-grown peppers used in our study may have differed in the quantity and characteristics of cuticular wax (Martin and Juniper, 1970). However, wax content was not examined. The interaction among cuticular wax characteristics, resistance to water loss, degree of water loss, and extent of 
pitting in peppers warrants further study.

While a sharp increase in $\mathrm{CO}_{2}$ production has been observed after bell peppers were transferred from 1 to 18C (Kozukue and Ogata, 1972), increased $\mathrm{CO}_{2}$ production may not be associated with CI (Tables 1 and 2). Peppers subjected to 1C maintained similar $\mathrm{CO}_{2}$ production regardless of whether $\mathrm{CI}$ developed (MG fruit) or not (ripe fruit). Fruit aging during storage was not responsible for the increased $\mathrm{CO}_{2}$ production, since $\mathrm{CO}_{2}$ production decreased in $\mathrm{MG}$ and ripe fruit stored at $13 \mathrm{C}$. Therefore, the increased $\mathrm{CO}_{2}$ production from greenhouse-grown peppers exposed to $1 \mathrm{C}$ apparently is a physiological response of exposure to $1 \mathrm{C}$ rather than a response related to $\mathrm{CI}$ development.

The elevated (18x) $\mathrm{C}_{2} \mathrm{H}_{4}$ production could be used as a sensitive indicator of exposure to chilling temperature in peppers (Table 1). This stimulation of $\mathrm{C}_{2} \mathrm{H}_{4}$ production is similar to the response observed in other tropical plant species (Tong and Yang, 1987) such as papayas (Chan et al., 1985) and cucumbers (Wang and Adams, 1982). Stimulation of $\mathrm{C}_{2} \mathrm{H}_{4}$ production is not unique for chilling-injured $\mathrm{MG}$ peppers, since $1 \mathrm{C}$ storage also stimulated $\mathrm{C}_{2} \mathrm{H}_{4}$ production (7x) in ripe fruit without $\mathrm{CI}$ development (Table 1). The chilling-induced increase in $\mathrm{C}_{2} \mathrm{H}_{4}$ production without a concomitant increase in pitting indicated that $\mathrm{C}_{2} \mathrm{H}_{4}$ may not play any role in CI symptom development in peppers. Similar results were observed in other chilling-sensitive crops (Tong and Yang, 1987).

CI in MG peppers was accompanied by elevated ACC concentration after 2 weeks of storage (Table 1). ACC is the only biological substrate for ACC oxidase (Yang and Hoffman, 1984). Most plant tissues are capable of metabolizing ACC to 1-(malonylamino) cyclopropane-1-carboxylic acid (MACC); but, under normal physiological conditions, MACC, the conjugated product, is a biologically inactive end product and is not converted to $\mathrm{C}_{2} \mathrm{H}_{4}$ (Jiao et al., 1986). The accumulation of ACC upon transfer from chilling to nonchilling temperatures also was observed in cucumbers (Wang and Adams, 1982). Ripe peppers at 1C showed a similar enhancement of ACC concentration without CI development. Therefore, a chilling-induced increase in ACC concentration is another chilling response that does not seem to be involved in pitting.

CI in MG peppers was associated with reduced ACC oxidase activity (Table 1). This reduced ACC oxidase activity is similar to that observed in cucumbers (Cabrera and Saltveit, 1990). MG peppers stored at 13C, however, showed similar low ACC oxidase activity as chilled fruit. Reduced ACC oxidase activity may be a characteristic of $\mathrm{MG}$ and ripe peppers, since stored ripe fruit also had reduced $(0.3 \mathrm{x})$ ACC oxidase activity.

Production of $\mathrm{C}_{2} \mathrm{H}_{4}$ did not correlate with ACC concentration $(r$ $=0.32, P=0.05, \mathrm{n}=36)$ or ACC oxidase activity $[r=(-0.15), P$ $=0.38, \mathrm{n}=33$ ]. These results are similar to those observed for cucumbers (Cabrera and Saltveit, 1990).

Cultivar. There was no cultivar $\times$ temperature interaction in $\mathrm{CI}$ development. MG fruit of 'Bison' and 'Doria' developed CI at $1 \mathrm{C}$, while CI did not develop in ripe fruit of either cultivar. On the contrary, there was a cultivar $\times$ temperature interaction in $\mathrm{C}_{2} \mathrm{H}_{4}$ production. Ethylene production by 'Bison' fruit exposed to $1 \mathrm{C}$ was 2.5 times that of fruit exposed to $13 \mathrm{C}$, while the corresponding increase for 'Doria' fruit was 13.6x. These differences in cultivar responses to temperature treatment in $\mathrm{CI}$ and $\mathrm{C}_{2} \mathrm{H}_{4}$ production again support the hypothesis that $\mathrm{C}_{2} \mathrm{H}_{4}$ production plays no direct role in CI of peppers.

\section{Conclusion}

The susceptibility of greenhouse-grown peppers to CI depends on their degree of ripeness. Pitting occurred only in MG fruit that were stored at $1 \mathrm{C}$ for 3 days or longer. Fully ripe peppers were not susceptible to CI when they were stored at $1 \mathrm{C}$ for up to 2 weeks. These ripe peppers showed no pitting after being returned to room temperature for an additional week. These observations suggest that ripe greenhouse-grown peppers could be handled commercially at much lower temperatures than those recommended for MG peppers. However, the minimum temperature at which they could be held and the maximum duration of storage without CI in ripe greenhouse-grown peppers require further investigation.

Previous studies have suggested that there was a connection between the increased $\mathrm{CO}_{2}$ and $\mathrm{C}_{2} \mathrm{H}_{4}$ production after exposure to chilling conditions and CI symptom development. By using two ripeness stages of peppers that have different sensitivities to the development of $\mathrm{CI}$ symptoms, we have shown that chillinginduced increases in $\mathrm{CO}_{2}$ and $\mathrm{C}_{2} \mathrm{H}_{4}$ production are not involved directly in $\mathrm{CI}$ symptom development. While our data support the use of enhanced $\mathrm{CO}_{2}$ and $\mathrm{C}_{2} \mathrm{H}_{4}$ production to indicate that chillingsensitive tissue has been exposed to chilling temperatures, it shows that enhanced production of these gases may not be a reliable indicator of CI symptom development.

\section{Literature Cited}

Abeles, F.B., P.W. Morgan, and M.E. Saltveit, Jr. 1992. Ethylene in plant biology. 2nd ed. Academic Press, New York.

Autio, W.R. and W.J. Bramlage. 1986. Chilling sensitivity of tomato fruit in relation to ripening and senescence. J. Amer. Soc. Hort. Sci. 111:201-204.

Bakker, J.C. 1989. The effects of air humidity on growth and fruit production of sweet pepper (Capsicum annuum L.). J. Hort. Sci. 64:41-46.

British Columbia Ministry of Agriculture and Fisheries. 1988. Nursery, greenhouse, vegetable, and ornamental 1988/89 production guide for commercial growers. B.C. Ministry of Agr. and Fisheries, Victoria.

Cabrera, R.M. and M.E. Saltveit. 1990. Physiological response to chilling temperatures of intermittently warmed cucumber fruit. J. Amer. Soc. Hort. Sci. 115:256-261.

Chan, H.T., S. Sanxter, and H.M. Couey. 1985. Electrolyte leakage and ethylene production induced by chilling injury of papayas. HortScience 20:1070-1072.

Hardenburg, R.E., A.E. Watada, and C.Y. Wang. 1986. The commercial storage of fruits, vegetables, and florist and nursery stocks. U.S. Dept. Agr. Hdbk. 66.

Jiao, X.Z., S. Philosoph-Hadas, L.Y. Su, and S.F. Yang. 1986. The conversion of 1-(malonylamino)cyclopropane-1-carboxylic acid to 1aminocyclopropane-1-carboxylic acid in plant tissues. Plant Physiol. 81:637-641.

King, M.M. and P.M. Ludford. 1983. Chilling injury and electrolyte leakage in fruit of different tomato cultivars. J. Amer. Soc. Hort. Sci. 108:74-77.

Kozukue, N. and K. Ogata. 1972. Physiological and chemical studies of chilling injury in pepper fruits. J. Food Sci. 37:708-711.

Lau, O.L., Y. Liu, and S.F. Yang. 1984. Influence of storage atmospheres and procedures on 1-aminocyclopropane-1-carboxylic acid concentration in relation to flesh firmness in 'Golden Delicious' apple. HortScience 19:425-426.

Lizada, M.C.C. and S.F. Yang. 1979. A simple and sensitive assay for 1aminocyclopropane-1-carboxylic acid. Anal. Biochem. 100:140-145.

Martin, J.T. and B.E. Juniper. 1970. The cuticles of plants. Edward Arnold, London.

Mencarelli, F., W.J. Lipton, and S.J. Peterson. 1983. Responses of 'Zucchini' squash to storage in low- $\mathrm{O}_{2}$ atmospheres at chilling and nonchilling temperatures. J. Amer. Soc. Hort. Sci. 108:884-890.

Miller, W.R. and L.A. Risse. 1986. Film wrapping to alleviate chilling injury of bell peppers during cold storage. HortScience 21:467-468.

Morris, L.L. and H. Platenius. 1939. Low temperature injury to certain vegetables after harvest. Proc. Amer. Soc. Hort. Sci. 36:609-613.

Phelps, D.C. and R.E. McDonald. 1989. Changes in fructose 2,6-bisphosphate levels in green peppers (Capsicum annuum L.) fruit in 
response to temperature. Plant Physiol. 90:458-462.

Risse, L.A., D. Chun, and W.R. Miller. 1987. Chilling injury and decay of film-wrapped and conditioned bell peppers during cold storage. Trop. Sci. 27:85-90.

Saltveit, M.E., Jr. 1977. Carbon dioxide, ethylene, and color development in ripening mature green bell peppers. J. Amer. Soc. Hort. Sci. 102:523-525.

Saltveit, M.E., Jr. 1991. Prior temperature exposure affects subsequent chilling sensitivity. Physiol. Plant. 82:529-536.

Saltveit, M.E., Jr., and L.L. Morris. 1990. Overview of chilling injury of horticultural crops, p. 3-15. In: Chien Yi Wang (ed.). Chilling injury of horticultural crops. CRC Press, Boca Raton, Fla.

Tong, C.B.S. and S.F. Yang. 1987. Chilling-induced ethylene production by beans and peas. J. Plant Growth Regulat. 6:201-208.
Wang, C.Y. 1977. Effect of $\mathrm{CO}_{2}$ treatment on storage and shelf life of sweet peppers. J. Amer. Soc. Hort. Sci. 102:808-812.

Wang, C.Y. and D.O. Adams. 1982. Chilling-induced ethylene production in cucumbers (Cucumis sativus L.). Plant Physiol. 69:424-427.

Wang, C.Y. and J.E. Baker. 1979. Effects of two free radical scavengers and intermittent warming on chilling injury and polar lipid composition of cucumber and sweet pepper fruits. Plant Cell Physiol. 20:243-251.

Yang, S.F. 1980. Regulation of ethylene biosynthesis. HortScience 15:238-243.

Yang, S.F. and N.E. Hoffman. 1984. Ethylene biosynthesis and its regulation in higher plants. Annu. Rev. Plant Physiol. 35:155-189.

Yao, K., L. Yu, and S. Zhou. 1986. A study of storage temperature and chilling injury on sweet pepper (in Chinese with English summary). Acta Hort. Sinica 13:119-124. 